\title{
Development of a Geodatabase for Springs Within and Surrounding Outcrops of the Trinity Aquifer in Northern Bexar County, Texas, 2010-11
}

\section{Introduction}

The Trinity aquifer is an important source of groundwater in central Texas, including Bexar County, where population growth has resulted in an increased demand for water (Ashworth, 1983; Mace and others, 2000). Numerous springs issue from rock outcrops within and surrounding the Trinity aquifer in northern Bexar County (fig. 1). The effects of increased groundwater withdrawals from the Trinity aquifer on springflow in the area are not well documented, but because the total amount of water entering, leaving, and being stored in a groundwater system must be conserved, increased groundwater withdrawals will result in decreases in springflow (Alley and others, 1999). Documenting the location, discharge, and basic water-quality information of the springs in northern Bexar County can provide a baseline assessment for comparison to future conditions. Accordingly, the U.S. Geological Survey (USGS), in cooperation with the Trinity Glen Rose Groundwater Conservation District, the Edwards Aquifer Authority, and the San Antonio River Authority, developed a geodatabase populated with data associated with springs within and surrounding outcrops of the Trinity aquifer in northern Bexar County during 2010-11. A geodatabase provides a framework for organizing spatial and tabular data (such as the geographic location and water-quality characteristics, respectively) in a relational database environment, making it easier and more intuitive to evaluate changes over time.

Data for 141 springs within and surrounding the Trinity aquifer outcrops in northern Bexar County were compiled from existing reports and databases. These data were augmented with selected data collected onsite, including the location, discharge, and water-quality characteristics of selected springs, and were entered into the geodatabase. The Trinity aquifer in central Texas is commonly divided into the upper, middle, and lower Trinity aquifers; all of the information that was compiled pertaining to the aquifer is for the upper and middle Trinity aquifers.

\section{Spring Locations and Characteristics}

Spring locations and characteristics were obtained from published reports, USGS 1:24,000-scale topographic maps, and available digital databases containing information on springs in the study area. Data from existing USGS reports (Heitmuller and Reece, 2003; Heitmuller and Williams, 2006; Clark and others, 2009), Joint Base San Antonio Camp Bullis (also referred to as "Camp Bullis"), Camp Stanley Storage Activity, and private property owners were included, as were discharge and specific conductance data collected during field reconnaissance.

The field reconnaissance of springs in the study area was done between October 2010 and September 2011 to verify the existing location data and collect additional data (discharge measurements, water-quality data, and property owner and photographic documentation) pertaining to the springs. A total of 46 of the 141 springs were visited during the field reconnaissance. Location data were collected by using a handheld Global Positioning System (GPS) unit or a digital camera with an integrated GPS unit, both with horizontal accuracy of tens of feet. Eight springs that discharge near the base of the Edwards aquifer outcrop were identified. The gradational nature of the contact between the Edwards and Trinity Groups made the exact location of the lithologic change difficult to determine. Furthermore, because of the steep terrain where these springs were located, the contact between the Edwards and Trinity Groups was sometimes indistinct.

Discharge at springs with flow ranged from 0.003 to 1.46 cubic feet per second. Most of the springs with flow were found in the outcrop of the upper and middle parts of the Trinity aquifer. Basic water-quality data were obtained from samples collected at selected springs. Specific conductance was measured in 21 springs and ranged from 167 to 1,130 microsiemens per centimeter at 25 degrees Celsius $(\mu \mathrm{S} / \mathrm{cm}$ at $25^{\circ} \mathrm{C}$ ). There were nine springs that measured between 600 and $1,130 \mu \mathrm{S} / \mathrm{cm}$ at $25^{\circ} \mathrm{C}$ for specific conductance. Of these, one was tentatively identified as issuing from hydrogeologic subdivision VIII of the Edwards aquifer, three from the cavernous hydrostratigraphic unit of the upper Trinity aquifer, one from the Camp Bullis hydrostratigraphic unit of the upper Trinity aquifer, two from the fossiliferous hydrostratigraphic unit of the upper Trinity aquifer, and two from the middle Trinity aquifer (fig. 2). Of the springs with a specific conductance less than $600 \mu \mathrm{S} / \mathrm{cm}$ at $25^{\circ} \mathrm{C}$, one was tentatively identified as issuing from hydrogeologic subdivision VIII of the Edwards aquifer, three from the cavernous hydrostratigraphic 


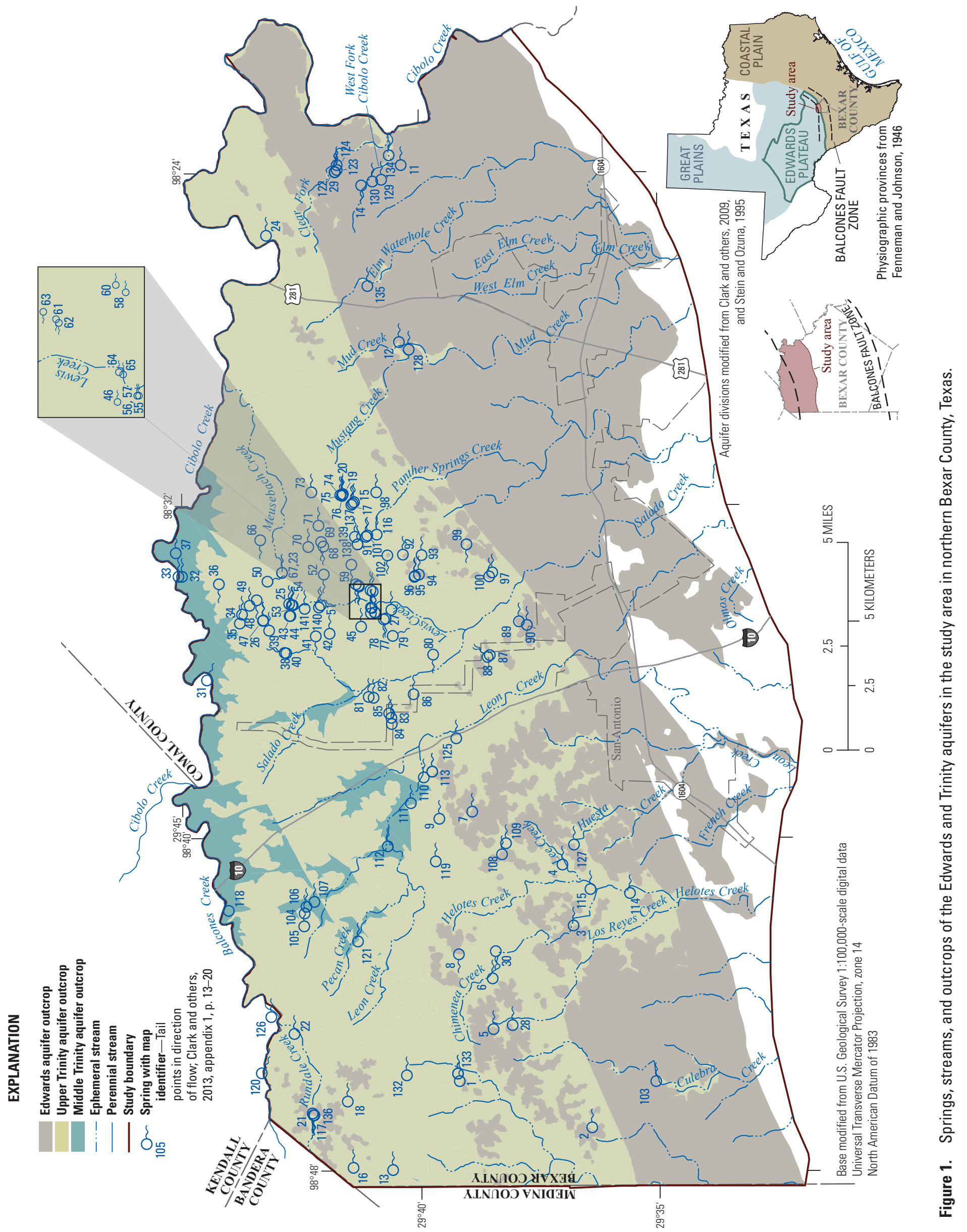




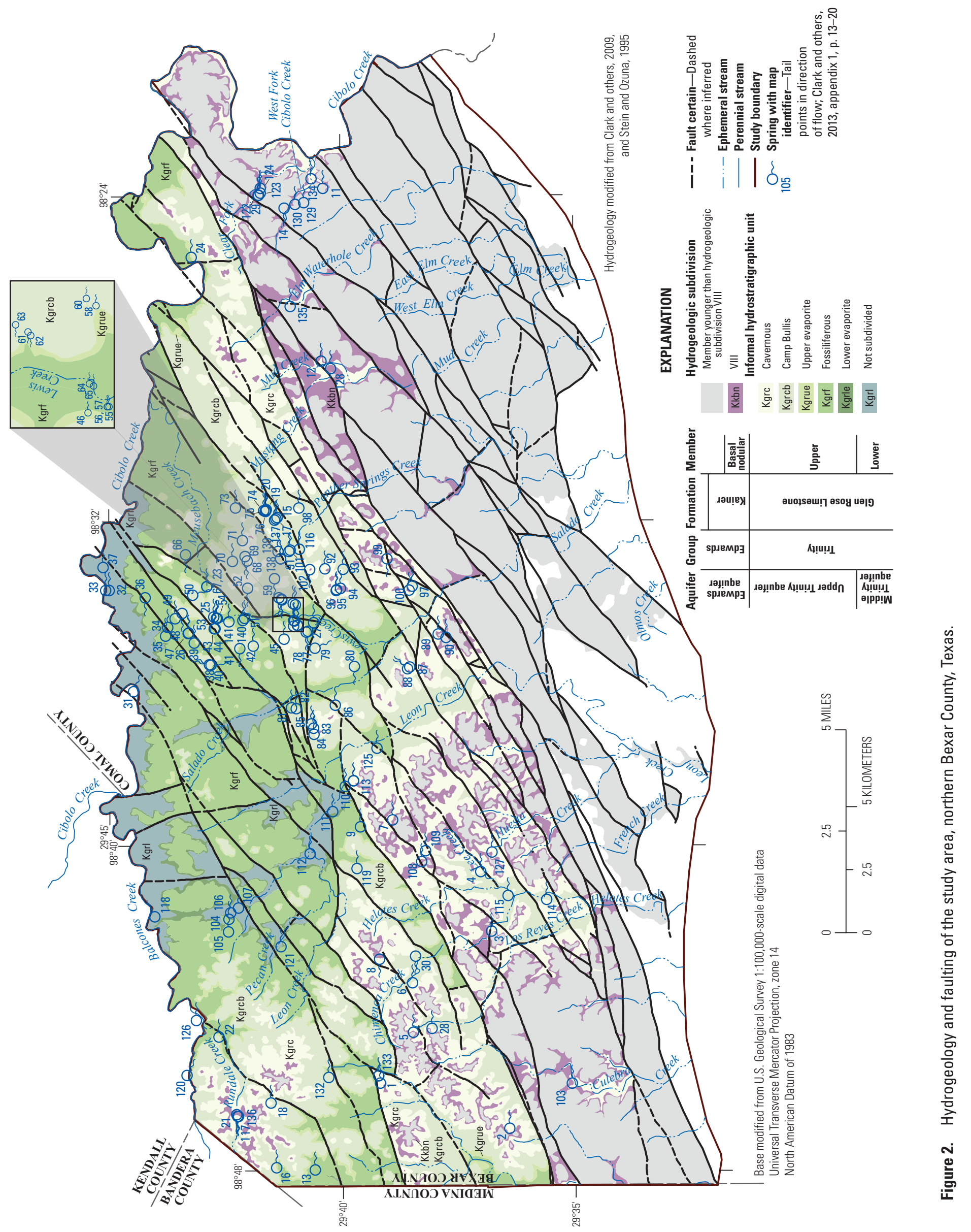


unit of the upper Trinity aquifer, two from the Camp Bullis hydrostratigraphic unit of the upper Trinity aquifer, one from the fossiliferous hydrostratigraphic unit of the upper Trinity aquifer, and four from the middle Trinity aquifer (fig. 2). Geochemical investigations including detailed water-quality analyses would help to confirm the aquifer or combination of aquifers that supply flow to each spring.

Increasing water demands are likely to continue to affect springflows throughout Texas. By completing reconnaissancelevel field investigations and compiling existing data, similar geodatabases could be developed for other aquifer systems in Texas.

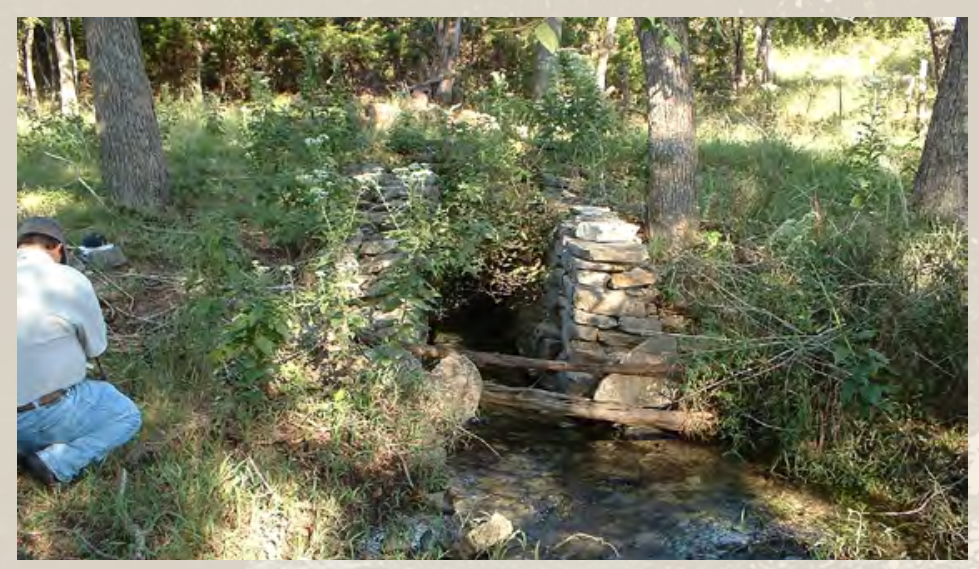

Spring near Leon Creek in the Trinity aquifer outcrop, northern Bexar County, Texas (photograph taken October 5, 2010).

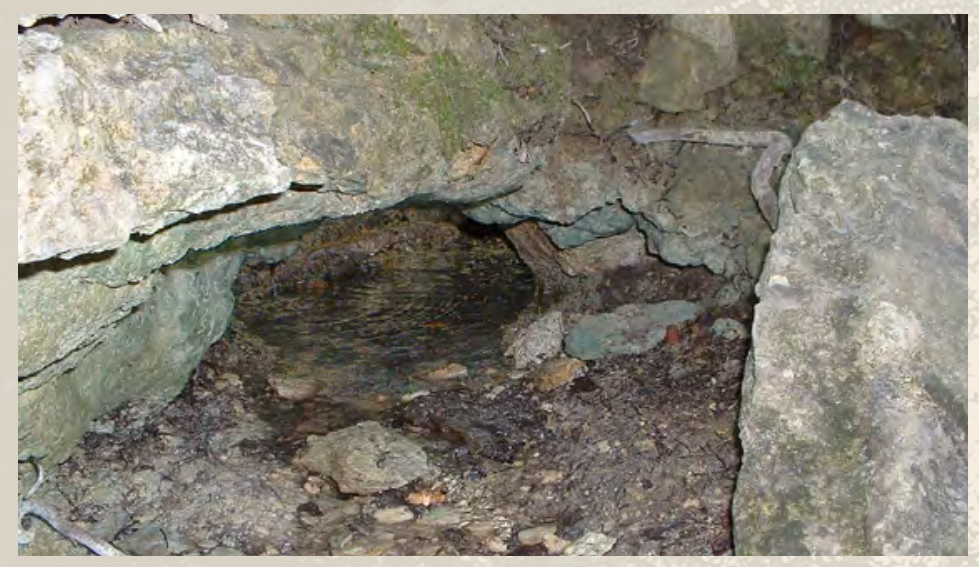

Spring near the headwaters of Leon Creek in the Trinity aquifer outcrop, northern Bexar County, Texas (photograph taken October 5, 2010).

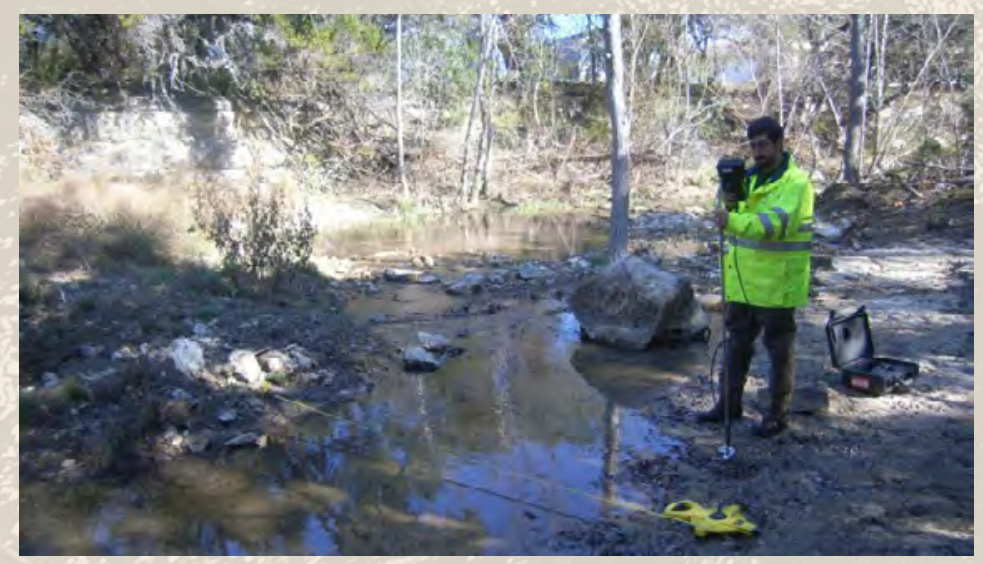

U.S. Geological Survey employee preparing to measure springflow discharging from a spring in northern Bexar County, Texas (photograph taken December 8, 2010).

\section{This fact sheet is based on the following USGS report:}

Clark, A.K., Pedraza, D.E., Morris, R.R., and Garcia, T.J., 2013, Geodatabase and characteristics of springs within and surrounding the Trinity aquifer outcrops in northern Bexar County, Texas, 2010-11: U.S. Geological Survey Data Series $750,20 \mathrm{p}$.

\section{References Cited}

Alley, W.M., Reilly, T.E., and Franke, O.L., 1999, Sustainability of ground-water resources: U.S. Geological Survey Circular 1186, 79 p. (Available at http://pubs.usgs.gov/circ/circ1186/.)

Ashworth, J.B., 1983, Ground-water availability of the Lower Cretaceous formations of the Hill Country of south-central Texas: Texas Department of Water Resources Report 273, 172 p., accessed March 22, 2011, at http://www.twdb.state.tx.us/ publications/reports/numbered_reports/doc/R273/Report273.asp.

Clark, A.K., Pedraza, D.E., Morris, R.R., and Garcia, T.J., 2013, Geodatabase and characteristics of springs within and surrounding the Trinity aquifer outcrops in northern Bexar County, Texas, 2010-11: U.S. Geological Survey Data Series $750,20 \mathrm{p}$.

Clark, A.R., Blome, C.D., and Faith, J.R., 2009, Map showing geology and hydrostratigraphy of the Edwards aquifer catchment area, northern Bexar County, south-central Texas: U.S. Geological Survey Open-File Report 2009-1008, 24 p., 1 pl.

Fenneman, N.M., and Johnson, D.W., 1946, Physical divisions of the United States: U.S. Geological Survey, 1 sheet, scale $1: 7,000,000$.

Heitmuller, F.T., and Reece, B.D., 2003, Database of historically documented springs and springflow measurements in Texas: U.S. Geological Survey Open File Report 03-315, 4 p.

Heitmuller, F.T., and Williams, I.P., 2006, Compilation of historical water-quality data for selected springs in Texas, by ecoregion: U.S. Geological Survey Data Series 230, 32 p.

Mace, R.E., Chowdhury, A.H., Anaya, Roberto, and Way, S.C., 2000, Groundwater availability of the Trinity aquifer, Hill Country area, Texas - Numerical simulation: Austin, Texas Water Development Board Report 353, $117 \mathrm{p}$.

Stein, W.G., and Ozuna, G.B., 1995, Geologic framework and hydrogeologic characteristics of the Edwards aquifer recharge zone, Bexar County, Texas: U.S. Geological Survey WaterResources Investigations Report 95-4030, 8 p.

\section{By A.K. Clark and D.E. Pedraza}

For additional information contact: Director, Texas Water Science Center U.S. Geological Survey 1505 Ferguson Lane Austin, Texas 78754-4501 http://tx.usgs.gov/

Publishing support provided by Lafayette Publishing Service Center 